\title{
Study on Optimization of Financial Sharing Service Center
}

\author{
Yao Li \\ Jinan University, Guangdong, China \\ Email: 695900560@qq.com
}

How to cite this paper: Li, Y. (2016) Study on Optimization of Financial Sharing Service Center. Modern Economy, 7, 1290-1302. http://dx.doi.org/10.4236/me.2016.711123

Received: September 8, 2016

Accepted: October 11, 2016

Published: October 14, 2016

Copyright (๑) 2016 by author and Scientific Research Publishing Inc. This work is licensed under the Creative Commons Attribution International License (CC BY 4.0).

http://creativecommons.org/licenses/by/4.0/

\begin{abstract}
The development of the information age promotes the upgrading of the financial management mode. As a new type of financial management mode, the Financial Sharing Center has been gradually applied and developed in the practical management of the enterprise. This paper reviews the development and existing problems of the Financial Shared Services Center at the level of theory and practice. Then according to the needle for the status of the group company, the article proposed the optimization method of financial shared services model of the group company.
\end{abstract}

\section{Keywords}

Financial Shared Service, Process Reengineering, Standardization

\section{Introduction}

With the development of economic globalization and information technology, the pace of internationalization of enterprises has been accelerating at an amazing speed, and the enterprises have set up branches in many countries. However, the expansion of the scale of branch institutions brought a lot of problems to the development of multinational companies. Seriously wasting of resources, overstaffed organization, loosely management, non-effective financial monitoring and so on, directly lead to highly cost and make enterprise fall into the severe financial risk and restrict the enterprise group further development and expansion. Under this background, the shared service management model arises at the historic moment, which can focus decentralized business functions on a new semi-autonomous business unit. The business unit has specialized management institutions, the purpose of which is to improve efficiency, create value, save the cost and improve the quality of service to internal customers [1]. According to a survey by the Institute of Certified Public Accountants in the United Kingdom, more 
than $86 \%$ of the Fortune 500 and more than half of European companies have been established or are establishing a shared service center [2].

At the end of twentieth century, the idea of sharing service was introduced into China. Through continuous digestion and understanding, shared service in China has gradually been accepted and respected, which reflects the great role of value in the enterprise management. ZTE took the lead in the establishment of the local financial sharing service center in 2005 , and successfully reduced the cost of the financial process to $50 \%$, and the average business processing capacity doubled [3]. Followed, some large enterprises such as Sinopec, China Mobile, Haier group, and Vanke Group, have been implemented or are planning to build financial services center. It is worth mentioning that, in the context of mobile Internet and cloud computing, local companies have begun to explore the financial sharing services into the cloud, and realize the idea of financial cloud services [4]. Financial shared service implementation integrates the enterprise strategy, enterprise business and enterprise finance, and provides more relevant, real time sharing information, promoting enterprise for sustainable value creation.

At present, the development of Financial Shared Service Center faces many challenges. Especially, how to maximize the advantages of Financial Shared Services is currently the major problem. Therefore, the enterprise must combine the characteristics of the industry and its own characteristics to optimize the Financial Sharing Service Center. This paper firstly analyzed the financial status and development of financial shared service center, and combined with the specific case of mining development experiences and existing problems. Secondly, proposed solution is to solve the existing problems. This article from four aspects of the organizational structure, information systems, business process, performance and staff management, carries out the design optimization of Enterprise Group Financial Sharing Service Center.

\section{The Development and Analysis on Present Situation of Sharing Center Service}

\subsection{The Theory Development of Sharing Center Service}

The thought of shared service center firstly raised by the United States Johnson \& Johnson, General Electric Company and Digital Equipment Corporation and other large enterprises in 1993, the core idea is shared human and technical resources and provide more efficient activities, create value for the organization [5]. The research of Financial Shared Services is relatively early in the foreign countries. Danna Keith \& Rebecca Hirschfield (1996) [6] put forward that the Financial Shared Service Center is a strong independent organization entity, which can integrated various content of business enterprise into relatively independent organizations, and charges on the business. Quinn (1998) [7] identified the shared services as a business model. According to the case study of Grant and Delvin (1999) [8], the success factors of Enterprise Financial Sharing Service Center are the following five aspects: people, the internal and external environment, the application method of BPR, the information technology and the 
change of enterprise vision. Kagelman and Schulman (2000) [9] pointed out that based on the process reengineering theory, integrate those auxiliary functions into the shared service center, which can provide the feasibility for the integration of internal resources. Bergeron (2003) [1] consider shared services is a cooperation strategic that can centralized a part of the existing management functions to a new semi-autonomous business unit, the business unit have a special management structure to improve efficiency, create value, save the cost and improve the quality of service to internal customers. Janssen and Joha (2008) [10] believes the key factors of the implementation of the Financial Shared Service of is the strict implementation of the strategy, business redesign, business process standardization, perfect information system, and revolutionary management. Martin (2011) [11] found the key elements of the successful implementation of the Financial Shared Services are site selection, strategic planning, process management, change management, organizational structure and the service level agreement of customer.

There is not yet reached a consensus conclusion about the value and function of Financial Shared Service Center, and most research focus on improving efficiency, reducing costs, improving service quality and so on. As for research on the construction of Financial Sharing Center Model, Zhang, etc. (2008) [12] using case study method to study the application of Financial Shared Service Center of ZTE and point that the key factors in the construction of financial sharing model are the standardization of financial system, the centralization of financial personnel, the process of financial management and the network of financial management. Duan (2009) [13] also using case study method to study a bank's Financial Shared Service Center construction. It is found Financial Shared Service Center besides to complete the key work, such as business process analysis, project planning and system development priorities, the supporting work of Financial Shared Service Center, such as organizational structure of financial regulation, financial management system, financial knowledge and system training, subject to approval process optimization also played a very important role. Zhou Changzhi (2010) [14] emphasized that the process standardization is very important for the efficient operation of the Financial Sharing Service Center, and it is the premise of the information centralized. However, how to carry out a complete implementation of the process of standardization is an important subject in front of management. In general, due to the uneven development of business and operating habits of the differences, the implementation of standardized operating procedures in the branch is not ideal. Therefore, the Financial Shared Service Center expected to achieve the desired results, the process must achieve a high degree of standardization. Huang Qinghua and Du Zhou (2014) [15] put forward that the key strategy for the enterprise to build financial shared service center is following four factors: effective management innovation and the transformation of the mode of thinking, standardized information platform unified, standardized financial system and operating procedures, internal control and the construction of financial early warning system.

At present, most of China's scholars concur that the Financial Shared Services is the product that enterprises implement financial restructuring and the organization inno- 
vation, and put forward that financial shared services realizes the aided creative breakthroughs in business process reengineering. However, the research on the construction of the financial sharing center model is less, and lack interaction with enterprise's overall management environment, and more limited to case studies, having non-universal applicability. Therefore, the study about construction method of Business Financial Shared Service Center in an integrated environment, exploring the organic connection of the finance and information platform and business activities, and reform of Financial Sharing Model of the working process and mode, both in theoretical level is still in practice, have very important significance. Based on this, this paper combined with literature reference and theoretical knowledge of the present, through the analysis of the current situation of the development of service center of financial conglomerates of Chinese share, summarize the experience effect and existing problems, and on the basis of optimization research.

\subsection{Development of Shared Services Practical}

Ford Motor Company in the early 1980s, took the lead in establishing the Financial Shared Service Center, and centralized its subordinate company's high duplication, standardization financial business on the center, and realized the Financial Shared Services of whole group [11]. Since then, DuPont and general electric have set up a global service business center and financial services. So far, more than half of the developed countries in Europe and the United States have established a shared service center. The application field of the foreign shared service center is also extended to other functional departments such as human resources, marketing, information technology and so on. In addition, in foreign mature financial field, the competition between the banks now also began to create a common business processing center.

The idea of sharing service was introduced in China at the end of twentieth Century, and gradually spread in multinational companies and domestic large enterprises. In 2004, HP established shared service center in Dalian, and provide shared services for the North Asia region as well as Japan, South Korea. November 28, 2006, Motorola's global accounting service center was officially settled in Tianjin. The center is currently responsible for $90 \%$ of the Motorola global accounts payable business, more than $80 \%$ of the company business, more than $80 \%$ of travel and reimbursement of business, more than $70 \%$ of the fixed assets, called Motorola of the Ministry of finance. In addition, domestic large local enterprises such as ZTE, Chang Hong, China Ping An insurance, the China Insurance Group, Haier Group, Guotai Junan Securities have established shared service center, and has achieved remarkable effect.

However, the application of shared service center in China encountered many problems and challenges, mainly in the following three aspects. Firstly, to manage and control enterprise is difficult. It is difficult to coordinate the "receiving power" in the process of financial reform, which is based on the corporate governance structure of the enterprise group. Secondly, the openness of the network system increases the risk of financial information distortion. On the one hand, if the software supplier can't ensure 
the security and integrity of the customer's accounting data in technical terms, the information may be leaked and damaged. On the other hand, in the network transmission and stored online may expurgate of electronic data, which leads to the accounting information be distortional. Thirdly, the ownership relationship between users and software suppliers is not clear. Accessing to external users Group enterprises stored the financial information in the far end, which is easy to cause disputes with unclear ownership [11].

\section{Analysis of the Current Situation and Problems of Financial Shared Service Center}

\subsection{Analysis of the Current Situation of Financial Shared Service Center}

According to the investigation report of 2015 Ernst Financial Sharing Service, since 2010, the construction of Financial Shared Service Center showed a trend of rapid growth. Especially, the number of enterprise whose financial shared service centers built in half year is accounted for the number of $28 \%$ less than five years to build. Currently, there are 53\% Financial Shared Services Center provide support for more than 50 points or subsidiary, and it is expected that the future will have $67 \%$ of the Financial Sharing Service Center will reach this scale. It shows that the Financial Sharing Service Center on the scale development is still very important. Research shows that Enterprises have Financial Shared Service Center in china Present the trend that geographical distribution from the eastern Bohai and the Pearl River Delta, Yangtze River Delta cluster transfer to the Midwest. In addition, there are two modes for financial shared service center location: single center and multi center. Single center refers to the Financial Shared Service Center is only a business career, and multi center is to establish two or more operations in the workplace. In the case of multi center, the center has the functions of many kinds of situations: regional center, process center and disaster recovery center. A regional center is provided according to the regional center, and each service center provides service for all process of the current region. The center of the process is defined for each service center in all areas, but the center undertakes the different processes and functions. Disaster recovery center refers to each center service in all areas and all flow and play a backup role between each other.

Moreover, survey results show that $64 \%$ of the Financial Sharing Service Center considers itself as the service sector, $25 \%$ positioning for the management department. At the same time, $50 \%$ think themselves are cost centers, $22 \%$ think is the profit center. It can be seen that the Financial Shared Service Center of the Chinese domestic enterprises is still dominated by the cost center model, and is more focused on the service orientation. In addition, most of the financial sharing service centers of the Chinese domestic enterprises do not carry out cost sharing and profit sharing, and it's common to carry out sharing and profit sharing by the application of the workload and 5\%-10\% profit margins.

At present, China's Enterprise Financial Sharing Service Center present the trend that providing services for the enterprise itself change to the third party, and presents 
the growth trend. Finally, the investigation report of 2015 Ernst Financial Sharing show that $72 \%$ of the Financial Shared Service Center has never employed service outsourcing, $17 \%$ has employed service outsourcing in the part of the process, $11 \%$ plans to use. In the enterprise that the financial service center has been outsourcing, 55\% outsourcing areas are the flows that requirements little financial, such as call centers, accounting records management. Secondly, Accounts Payable process outsourcing accounted for $20 \%$, accounts receivable process accounted for $16 \%$ of wages, salary accounted for $7 \%$, and general ledger the report accounted for $2 \%$. It shows that China's domestic financial Sharing Service Center for the financial process of service outsourcing acceptance is low, and amount of process outsourcing is also focused on the non-core financial processes.

\subsection{Problems Existing in Financial Shared Service Center}

The enterprise that have financial sharing service center already have a higher level of practice and application ability, but the development of the enterprise is not static. Therefore, the improvement and optimization of the operation of the Financial Shared Service Center is very important. Financial Shared Service Center is facing diversity challenges, covering information systems, communication mechanisms, personnel management, process optimization, service level upgrade, performance appraisal, personnel recruitment and so on. The main problems are analysis as follows.

Firstly, to manage and control enterprise is difficult. It is difficult to coordinate the "receiving power" in the process of financial reform, which is based on the corporate governance structure of the enterprise group, and may increase operating costs. In order to make the business process more standardized, organizational structure adjustment and optimization is essential.

Secondly, the standardization of the process is not enough. At present, China's enterprise group cannot be executed in strict accordance with the requirements of process management system and regulations, which is part of the repetitive process. And the degree of standardization process is not enough, which to a certain extent affected the Financial Shared Service Center operation efficiency and customer satisfaction.

Thirdly, the openness of the network system increases the risk of financial information distortion. On the one hand, if the software supplier can't ensure the security and integrity of the customer's accounting data in technical terms, the information may be leaked and damaged. On the other hand, in the network transmission and stored online may expurgate of electronic data, which leads to the accounting information be distortional.

Fourthly, the management personnel of Financial Shared Service Center not get enough specialized degree. Financial Shared Service Center (FSSC) as a combination of network and financial high-tech products, needs meet higher requirements on the professional level of financial personnel, legal awareness and professional ethics, and the overall quality. And it not only requires the financial personnel to have a very deep financial theory, but also requires them to master the corresponding computer applica- 
tion knowledge. More importantly, personnel of FSSC need to communicate with each department of the enterprise, and participate in strategic and decision-making. Due to the comprehensive requirements of personnel skills, FSSC cannot form a specialized division of labor, which can bring a high cost because of unbalanced load and the high demand on the quality of the staff.

Fifthly, the ownership relationship between users and software suppliers is not clear. Accessing to external users Group enterprises stored the financial information in the far end, which is easy to cause disputes with unclear ownership [16].

\section{The Optimal Design of Financial Shared Service Center}

\subsection{Reasonably Determine the Target of Financial Shared Service Center}

Evaluating, analyzing and developing a clear and reasonable vision orientation and strategic objectives of financial shared service center can make the enterprise plan and goal clear, which have an important role in financial shared mode constructing. In the past thirty years of economic development, the cause of China's enterprises magic is low-cost, so many scholars pointed out that the main driver of the shared service center is to improve efficiency and reduce costs. However, in my opinion, as a kind of model of the centralized financial management mode, the target of Financial Shared Service Center cannot be limited to improve the efficiency, reduce the cost, but to unify accounting standards, strengthen the abilities of group internal financial controlling and risk-management, thus providing support for corporate financial decisions and strategies implementation. Released by Ernst \& Young 2015 financial shared services survey report also shows that the cost savings is not Financial Shared Service Center's primary purpose, standardization and strengthen the ability of controlling is the core motivation and value of the Financial Shared Service Center.

\subsection{The Principle of Establishing the Financial Shared Service Model}

Financial Sharing Service Center is a new type of financial management model, and the implementation process will inevitably face a lot of pressure, mainly in the following four points. Firstly, the change of ideology is difficult. The concept that subsidiary independently seeking to maximize their own interests is difficult to change. Secondly, the organizational structure of financial adjustment. The business that dealt by company's financial sector is now shared by the Financial Sharing Service Center and the Department. Thirdly, the cost of starting is higher. Survey planning, development of information systems and the adjustment of organizational structure produce high costs and opportunity costs. Fourthly, staff emotional is instability. The establishment of professional and process standards and the promotion of information processing platform inevitably lead to a reduction in the number of financial personnel, and the employees stay in the Financial Shared Service Center will be conducted several rounds of training and examination, which to some extent will affect the employee's enthusiasm. Therefore, the construction of financial shared service model needs correct guiding 
principles. Firstly, adhere to the overall concept, based on the benefit of the whole enterprise group, mutual cooperation, coordination closely and strengthen management at all levels of personnel and financial personnel communication, and to ensure that the enterprise culture change gently. Secondly, financial model reforming is a long-term process, and in the long process of reform, establishing financial shared information platform, making the financial system and other business systems gradually be the integration of form. Thirdly, sort out and reengineer the financial process. Fourthly, to

ensure that the performance appraisal system and new business of financial sharing model adapt to each other [17].

\subsection{Optimization Path of Financial Shared Service Center}

The Treasury Department released the "Working standard of Enterprise Accounting" and explicitly requires:" the large-scale enterprises or enterprise groups that own many branch or subsidiaries, widely distributed should explore the way that use technology to promote the centralization of accounting work, and gradually establish a Financial Shared Service Center. The standard has pointed out the direction of the reform of financial management mode of group-company. As for enterprises, it is particularly important to do a good job in the construction of the system, process reengineering, the construction of the Internet, organizational change and functional innovation, and forming a better top-level design and service model.

\subsubsection{Form a Standard Financial Management System}

Implementation of the standardized financial management system is the base of construction of Financial Shared Services Model. Financial shared services standardize different business units of the business process through the establishment of a unified operation mode and operation process, and unified operational standards, thus different elements of the financial organization can deal with business through the same standards. Therefore, it is possible that the different operation have specialized division of labor, which reduces the skills of personnel requirements, and enable the lower cost of personnel into the financial management process, and that not only reached the objective that financial management should reduce costs, but also provide a guarantee that financial strategy of the group can be unified implementation. Financial Shared Services Centre have all financial data of enterprises related subsidiaries, and it is more easily to collect and analysis data, and more easily to achieve cross regional, cross sectoral integration of data, and display the data synergistic effect [17].

\subsubsection{Reform the Organizational Structure}

During the process of building the financial sharing service center, the group is faced with the core basic task of reforming its organizational structure. The reform in the financial organization should be mainly reflected in the transformation from the scattered organization to the concentrated organization. The financial sharing service is a typical mode of concentrated organization. Through the mode of separating the service end (sharing service center) and customer end (member units of the group), it can re- 
define the operation interface and relationship between the group and the units at the grassroots level (branch company). The financial personnel engaging in the standard financial work will be also removed from those member units and placed in the financial sharing service center. Hence, it can realize the concentration of financial personnel. What is more, two departments in parallel with the financial sharing service center can be also formed to classify the functions of financial personnel as well as strengthen the function of strategic financial management. Those two departments are known as the operation financial department and strategic financial department. To be more specific, the operation financial department will assist those member units to evaluate the operation value. The financial personnel in the department will provide various services, such as the analysis, consultation and decision-making support, for the front-line units. They will also lend support to the member units when they are enhancing the ability for operation and management as well as achieving the strategic goal and operation plan. In a word, the strategic financial department plays a key role in the decisionmaking. The financial personnel in the department will participate in the operation and management at the level of head office. They will also provide the support for strategic decision-making.

It should be noted that the group will be under the pressure from all sides during the process of organizational reform. For the group that involves a complicated business structure and covers a large region, it can consider adopting the modular implementation according to their actual condition and the principle of importance. Under the principle of being unified and standardized, the group can carry out the pilot project in the local area and then apply it to wider areas gradually. After that, the local sharing and overall integration will be put into practice. During the implementation, the project team should lay out the strategy accordingly, including the timely communication and transparent information. In addition to the classification and communication, the current status of the personnel concerned should be also analyzed. The incentive should be given to those responding to the project actively so that the financial sharing strategy can be executed effectively. Besides that, the whole group will reach an agreement.

\subsubsection{Build Financial Sharing Information Platform}

As noted by Arthur Anderson in 1997, modern technologies will play a key role in supporting the concept of sharing service as well as integrating the cross-border information with the financial system [12]. The success of financial sharing service center should be reliant on the support of powerful information system. All financial systems, including the financial operation standard and process, should be integrated into the unified database through the IT platform in the financial sharing service center so that the strategy of the head office can be implemented effectively. In addition, the financial information system built by the financial sharing service center should cover all aspects of the operation and management in the company. Moreover, the unity of data standard, system access and information between different systems should be also realized so as to ensure the smooth exchange of data. The authority in the financial information system should be delegated to those members strictly. Those member units should not 
be at liberty to modify the system so that the authenticity and reliability of financial information can be guaranteed.

The building of financial sharing information platform may be faced with a variety of problems, such as the poor timeliness of information transmission, the storage of massive data, and the safety hazard in the transmission as well as the lack of scientific methods for financial information management. The emergence of financial cloud has offered a potential solution to those problems. By integrating the financial sharing management mode of the group with the computer technologies such as cloud computing, mobile internet and big data, it can integrate the financial sharing service center, financial management center and fund management center into a coherent whole. The concentrated and unified financial cloud center will be built to support the multi-terminal access mode. Besides that, it can also realize the collaborative application of the accounting, reimbursement, fund and decision-making in the whole group. At present, many enterprises have tried to resort to the Wechat platform for reimbursement application. Based on the employee credit system, the sampling review will be made after the reimbursement, thus greatly improving the timeliness and satisfaction degree for those front-line employees. The cloud computing is based on the internet. With the aid of cloud computing, the financial information can be extracted more accurately. Moreover, the cloud storage with infinite resources can provide the most comprehensive financial information in a timely manner, thus overcoming the limitation in terms of space and time. Hence, the problem of isolated information island will be also solved according. Through the extraction of financial elements and the storage of financial information, the financial information center can function as a data center which is capable of data analysis and mining. It can also offer the financial index and motivation analysis for the enterprises concerned. Besides making the early warning, it can create more commercial value for the group.

\subsubsection{Carry out Process Reengineering to Ensure the \\ "Three Flow" Synchronization}

How to rebuild the financial process to achieve physical flow, information flow and capital flow of the Financial Sharing Service Center synchronization is the key issue to build a financial shared services model [15]. The process reengineering of the financial sharing service should follow the six principles, as shown in Figure 1.

The so-called Precision elements is in original document elements extracted as needed for processing the data, in order to realize the flexible combination of the elements of audit, and have a better implementation of the factory management [4]. Establish data standards, and achieve the only definition within the group, realizing interoperability, avoiding the system everywhere, island everywhere, which can easy to carry out business and management decisions in the same context. Specialization, detailed division of labor in the service process of the Financial Sharing Center, and each financial staff only handle limited financial operations, which can maximize the effect of economic scale. Standardization of procedures, on the basis of combing internal flow, homogenize integration business, and reduce non-value added services, and 


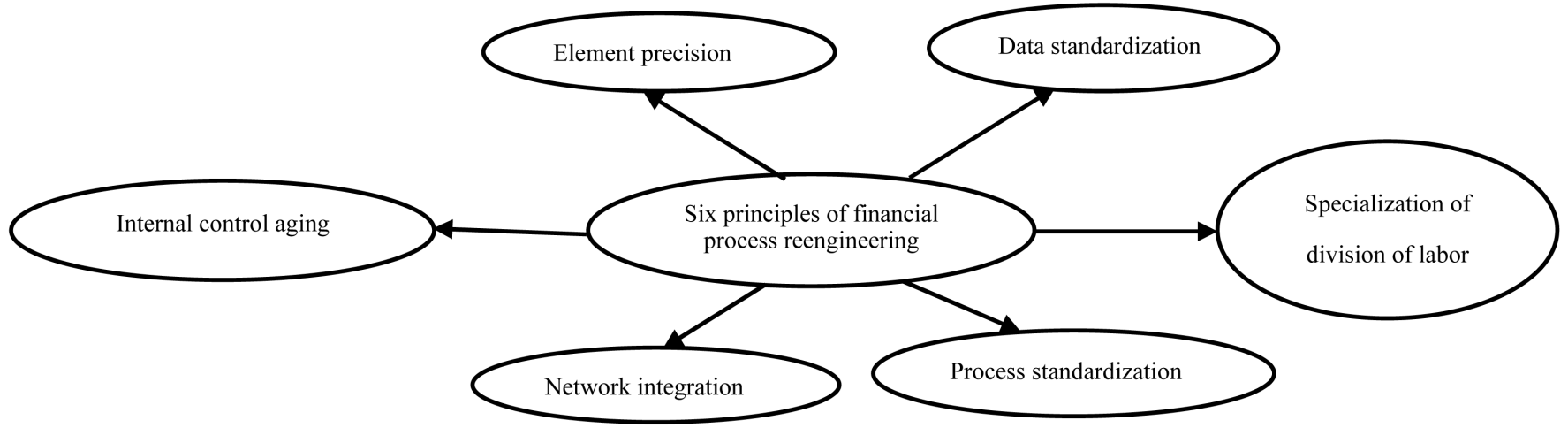

Figure 1. Six principles of financial process reengineering.

ensure that each process is necessary, at the same time, lay down a criterion in order to make the financial business more efficient and orderly. Network integration is that all financial information is integrated in a unified Internet platform, and any port can obtain the required financial information within the scope of authorization. In addition, through the construction of image system, it can realize the cross space of financial information transmission, which makes the real-time information exchange and data sharing, thus greatly improving the efficiency of information extraction and exchange. Internal control of aging is that refers in the process of financial process redesign embedded audit node, all need to audit risk control to embed information system, instead of manual audit by the system to achieve precise control.

\subsubsection{Make Innovations in Financial Personnel Functions}

The reform in the financial organization will be necessarily accompanied by the change in the functions of financial personnel. Under the mode of financial sharing, the function of financial management can be divided into three levels, namely the strategy supporting the financial management, the operation supporting the financial management as well as the financial sharing service center. To be more specific, the strategy supporting financial management is mainly aimed at the tax policies and planning, investment and financing as well as internal auditing and risk control in the whole group. Hence, it aims to provide the support for the long-term comprehensive strategy. The operation supporting financial management is mainly concerned with the operation plan and budget, business mode analysis and cost management, which are closely related to the industry concerned. The sharing service center is responsible for the large quantity of simple and repeated accounting work in the group. It will also lead to the economics of scale for the financial work, thus serving the group at all levels.

Before the financial sharing, all the financial functions of those enterprise entities and financial departments in the group are integrated. After the implementation of financial sharing, the financial function can be divided and distributed at different levels, thus leading to the more scientific and professional division of labor. After the functional division of decision-making support, operation support and accounting support, the authority for management should be delegated to those concerned at all levels. Un- 
der the principle of the unified management in the group, the parent company will lay out the management system for the head office. Under the guidance of the management system, those branch companies will design the financial management system at their own level. According to the management concept of operation, post and personnel division, the financial sharing center can build an accounting factory featured by being product-oriented, standardized and process-oriented. Under this mode, the personnel function can be further divided into three categories, namely the accounting, internal control and management. The accounting personnel are made up of those workers in the accounting product line. They are merely engaged in the repeated labor without needing the professional judgement. The internal-control personnel are responsible for the production control and on-site management. The management personnel will mainly take responsibility for the standardization and information of production material and mode. The concept of hierarchical management can better facilitate the delicacy management of the group under the complicated business circumstance.

\section{Conclusion}

In summary, the optimization of financial sharing services model is a gradual change, during which full communication and perfect risk control run through the whole process. The key to the optimization of financial sharing services center is standardization, processes, information and innovation. When information technology updates constantly, enterprises should take the opportunity to accelerate the overall financial transformation.

\section{References}

[1] Bergeron, B. (2002) Essentials of Shared Services. John Wiley \& Sons Inc.

[2] Hu, C. and Ying, L. (2011) Financial Shared Services Industry Survey Report. China Financial \& Economic Publishing House, 8-12.

[3] Zhang, R.J., Chen, H. and Zhang, Y.J. (2010) Research on the Key Factors of Business Enterprise Group Financial Sharing Service Process Reengineering-Based on the Management Practice of ZTE. Corporation Accounting Research, 7, 57-64.

[4] Hu, J., Liu, B.M. and Yu, J.M. (2014) Research on the Construction of Financial Cloud of Group Company Based on Intelligent Era. Chief Accountant of China, 10, 80-81.

[5] Huang, Z.F. (2014) Research on the Construction of Financial Shared Service CenterBased on the Case Study of Y Bank. Xiamen University, 1-59.

[6] Keith, D. and Hirschfield, R. (1996) The Benefits of Sharing. HR Focus, 73, 15-16.

[7] Quinn, B.E., Cooke, R. and Kris, A. (2000) Shared Services: Mining for Corporate Gold. Financial Times Prentice Hall.

[8] Grant, F. and Delvin, J. (1999) A Using Existing Modeling Techniques for Manufacturing Process Reengineering. A Case Study. Computers in Industry, 8, 102-111. http://dx.doi.org/10.1016/s0166-3615(99)00011-1

[9] Triplett, A. and Scheumann, J. (2000) Managing Shared Services with ABM. Strategic Finance, 8, 40-45.

[10] Janssen, M. and Joha, A. (2009) Emerging Shared Service Organizations and the Service- 
Oriented Enterprise Critical Management Issues. Strategic Outsourcing. An International Journal, 16, 35-49.

[11] Martin, W. (2011) Critical Success Factors of Shared Service Projects-Results of an Empirical Study. Advances in Management, 14, 21-26.

[12] Zhang, R.J., Chen, H., Hu, Y.G. and Chang, Y. (2008) Research and Practice of Financial Shared Service Model. Management Case Studies and Reviews, 3, 19-26.

[13] Duan, P.Y. (2009) Analysis and Research on Typical Cases of Financial Shared Service Center. Financial Accounting, 9, 21-26.

[14] Zhou, C.Z. (2010) A Preliminary Study on the Establishment of a Shared Financial Center in the Enterprise Group-A Case Study of China Life Insurance Group. Legal System and Economy, 5, 96-98.

[15] Huang, Q.H., Du, Z., Duan, W.C. and Yang, X. (2014) Research on the Model of Financial Shared Service Center. Economic Problem, 7.

[16] Huang, Q.H., Du, Z., Duan, W.C. and Yang, X. (2014) Research on the Model of Financial Shared Service Center. Economic Problem, 7, 108-112.

[17] Hu, Z.X. (2013) Research on the Financial Sharing Service Model of Group Enterprises. Metallurgical Accounting, 6, 13-17.

\section{Submit or recommend next manuscript to SCIRP and we will provide best service} for you:

Accepting pre-submission inquiries through Email, Facebook, LinkedIn, Twitter, etc. A wide selection of journals (inclusive of 9 subjects, more than 200 journals)

Providing 24-hour high-quality service

User-friendly online submission system

Fair and swift peer-review system

Efficient typesetting and proofreading procedure

Display of the result of downloads and visits, as well as the number of cited articles

Maximum dissemination of your research work

Submit your manuscript at: http://papersubmission.scirp.org/

Or contact me@scirp.org 